\title{
Intangible assets - insights from a literature review
}

\author{
Elena-Mirela Nichita ${ }^{\mathrm{a}, 1}$ \\ ${ }^{a}$ Bucharest University of Economic Studies, Romania
}

\begin{abstract}
Research Question: How do researchers address the definition, measurement, recognition and potential of intangible assets to generate future economic benefits when a formal structure for reporting them is highly controversial? Motivation: The inexistence of inclusive reporting mechanism to capture the value of intangible assets rise many debates for both researchers and users of accounting financial reports (Jeny and Moldovan, 2016). Although the role of intangible resources is increasing in the modern economy (OECD, 2011), traditional reporting is unable to provide a comprehensive representation of this class of assets (Lev, 2000; Stolowy and JenyCazavan, 2001) and many intangible assets are still not recognised or may even not referred at all in the financial statements (Barth et. al., 2000). Idea: The paper investigates the status-quo of intangibles in research papers and identifies blank spots and ways to improve the information on intangible assets and how IASB revised IAS 38 Intangibles to catch-up the business' challenges in regard with them. Data: The sample of current work comprises research papers about intangibles published during 2000-2019 in cutting-edge accounting and business journals. Tools: The content analysis of published papers was applied to discover categories of intangibles analysed, applied polices for measurement, debates on recognition and disclosure and potential of new intangibles to be reported. Findings: Conclusion of paper confirms that researches on intangibles have not arrived at a universally accepted framework for definition, measurement, recognition criteria, disclosure, but, in the same time, they emphasis the contribution of these resources to broaden competitiveness, performance, earnings. Contribution: This literature review covers all categories of intangibles - recognized and not-recognized from accounting
\end{abstract}

\footnotetext{
${ }^{1}$ Corresponding author: Elena-Mirela Nichita, Department of Accounting and Audit, The Bucharest University of Economic Studies, Piata Romana, nr. 6, tel.:+40 745.972.468; email address: mirela.nichita@cig.ase.ro
} 
perspective - explored in research papers from the latest 19 years and provide an interpretative approach for further investigation.

Keywords: intangible assets, literature review, research, measurement, recognition, disclosure

\section{JEL codes: M41}

\section{Introduction}

The topic of intangibles has been controversial and a source of debate for many years. A wide range of definitions and classifications of intangibles have been proposed over the time to make available a better accepting of concept, achieve reliable measurement, and encourage understanding and communication between investors, researchers, and management. Nowadays, the importance of intangible assets has increased both for economies, and for entities (Duizabo \& Guillaume, 1996; OECD, 2011; Stewart, 1997; Zeghal, 2000).

This paper attempts to present a literature review on the financial accounting's features of intangibles concerning evaluation, measurement, recognition, disclosure and reporting to external users based on a selective researches published during 2000-2019 in highly qualitative journals. Selectivity is indispensable given the voluminous topics that comprise financial accounting research, in general, and intangibles, in particular (Callen, 2015). The paper will highlight a review of the history and difficulties faced by International Accounting Standards Board (IASB) to standardise the issues of intangibles with the critical goal of underlining the thoughtful issues regarding intangible assets.

International Accounting Standards Committee (IASC), now International Accounting Standards Board (IASB), issued International Accounting Standard 38 in July 1998 (IAS 38 Intangible assets, following the publication of two Exposure Drafts: E37 Research and development costs, respectively, E50 Intangible assets (E59 Intangible assets is E50 modified). The standard sets out proposals for the definition, recognition criteria, measurement, amortization, and disclosure of intangible assets.

The work of many researchers puts into the light the necessity of improvements in reporting of intangibles to achieve the objectives proposed by Conceptual Framework in respect to essential resolution providing useful and qualitative information to users. This statement comes after analysing (a) definition, recognition, measurement and evaluation of intangible assets (El-Tawy and 
Tollington, 2018), (b) influence of intangibles on companies'value, (c) relationship between intangible assets and stock price (Abdolmohammadi, 2005; Gerpott, et al., 2008; Orens et al., 2009; Petty et al., 2008), cost of capital or riskiness of investment (Aboody and Lev, 2000; Seow et. al., 2006) or governance (Biondi \& Reberioux, 2012). Additionally, the imperfection of market due to information asymmetry (Akerlof, 1970) may create opportunities for misreporting intangible assets and for generating information's disproportionateness between internal users and external users of financial information (Zeghal \& Maaloul, 2011).

The aim of current research paper is to offer a literature review on the subject of intangible assets, with an analysis about (1) how IASB reviewed the standard in respect to intangible assets, (2) difficulties in defining intangibles, (3) what philosophies were applied in measurement and recognition of intangibles, (4) what element classified as intangible assets impact the business performance, (5) how should accounting professional should display information about intangible assets, and (6) how investors feel about intangibles when they decide to invest into a business.

This literature review is organized as follows. In the next section, the contextual and motivation in investigating intangible assets will be expounded. The data and method of this study are detailed in the research design and data collection section. The results of the examination will be described and their consequences summarized in the results section. To conclude, comparisons result with the previous studies will be discussed in the final paragraph of this paper.

\section{Intangible assets across academic literature}

To study the current state and future consequences and magnitudes of intangibles in financial accounting and reporting is necessary for the reason that they create competitive advantages to entities.

\subsection{Considerations on definition of intangible assets}

In a legal, economic or business-related circumstance, there are many different terms that follow intangible concept: intangibles, intangible assets, intangible values, intellectual capital, intellectual property, knowledge assets, invisible assets. They either characterize a particular area of intangibles or are used interchangeably to designate the intangible vision, in general.

The development and advancement of intangibles has uncovered the limitations of the existing accounting model (Egginton, 1990). The professionals have joined the academic literature in arguing that the current systems of accounting and reporting 
are insufficient and inadequate to fully capture the value created by business models that are driven by innovation and intangible assets (Gruber, 2015; Reilly \& Schweihs, 2014; Vallejo-Alonso, 2010). The disagreement refers to characteristics of economy based on production, consumption, trade of physical goods which is no more suitable for an economy based on knowledge, skills, emotions, creativity, innovation, intangible experience, technologies, artificial intelligence, internet of things (Blair \& Wallman, 2001; OECD, 2006; Bond \& Cummins, 2000, Gruber, 2015; Reilly \& Schweihs, 2014).

IAS 38 Intangible assets (ifrs.org) states "An intangible asset is an identifiable, nonmonetary asset, without physical substance". The adopted definition underlines that intangible are assets which means fulfil the definition of assets presented in Conceptual Framework, are not a monetary item, and are without any corporeal constituent. Considerate assets, intangibles are "resources controlled by entity ... which future economic benefits are expected to flow to the entity" (Conceptual Framework, par. 4.4. (a)) and there is a probability of future economic benefits and the cost can be reliable (Conceptual Framework, par. 4.38). In light of new project of Conceptual Framework, the assets are defined as "present economic resources controlled by the entity as a result of past events. An economic resource is a right that has the potential to produce economic benefits" (Project Summary, 2018). Consequently, there is a shift from resources with future inflow of benefits to present resource with potential to gain benefits.

International Valuation Standard Committee (IVSC) uses the list-based approach (Stolowy \& Jeny-Cazavan, 2001) in respect to define intangible assets: assets deriving from rights (franchise agreement), assets based on relationship (relationship with clients, suppliers, distributors, employees), intellectual property (patent, trademark, industrial property objects) (Vidrascu, 2013).

Stolowy and Jeny-Cazavan (2001) identified two approaches applied by national regulation organisations from European countries and North America, when they explain intangibles: conceptual approach and list-based approach. The conceptual approach brings up the (1) tautological definition of assets - "immateriality" feature of intangibles, (2) definition by opposition - "other than", and (3) real definition - a sincere and genuine determination to construct a relevant definition. The second approach is based on a list of elements, similar with a catalogue.

The work of Blair and Wallman (2003) puts forward a definition of intangibles highlighting the impossibility of trading these elements on market because their lack of physical form, with a volatile value and connected to a specific business sector or activity: "intangibles are non-physical factors that contribute to, or are used in, the production of goods or the provision of services or that are expected to generate future productive benefits to the individuals or firms that control their use". 
As Andriessen (2004) points out, the issue of intangible resources is that they are intangible. The semantic meaning of the adjective intangible is unable to be touched, not having physical presence or difficult to describe, understand or measure or difficult to define; or simply not tangible. "Intangible" refers various complementary notions which are no different in form and substance such as intangible investments, intangible capital, intangible assets.

Ochs (1996) considers intangibles as a "dynamic intangible investment which incorporates a share of dominant knowledge that contributes in a specific or in a process way to the competitiveness and to the company's value". All assets (investments), either tangible or intangible are under scrutiny of uncertainty and professionals uses their judgment and experience to anticipate the future benefits (Conceptual Framework, 2010; Fisher, 1930; Wyatt, 2008).

There are a wide variety of definitions for the concepts intangible assets; if intangibles are predisposed to future benefits, why there is not an agreement in defining them or why the accounting profession is not talented to entirely capture their potential and permits multiple analysis and interpretations? (Canibano, 2000).

\subsection{Considerations on classification of intangible assets}

To formulate a classification is necessary to identify a purpose of classification; the criteria chosen can never to true or false, only more or less useful according to the advocated purpose of classification (Khalidi, 2013). Accounting uses classification of elements for different reasons: establishing liquidity of assets, establishing solvency of liabilities, identifying measurement basis to develop solutions for evaluation since there are options for evaluation basis: the preference for historical costs for non-current assets and liabilities or the preference for fair value for financial assets and liabilities. In respect of intangible assets, researchers conclude that is problematic to find a purpose for classification of intangibles (Abeysekera, 2016; Nobes, 2018; Walker, 2009). However, management purpose seems to be trustworthy because managers endeavour to create and run a successful business and they have to organise and label all available resources by putting them in different categories (Kaufman \& Schneider, 2004).

The research conducted by Wyatt (2008) concerning value-relevance of intangibles, organizes the intangibles in three categories representing the business resources as follows: technology resources (R\&D expenditures and related intellectual property), human resources (human capital), production resources (brands, customers' loyalty) and competitive advantages (goodwill). Lev (2001) considers four groups of intangibles: organizational capital (business processes, corporate culture, chart of company, structures), human resources, customers related intangibles (brand, trademark) and discovery-learning category (research and development costs). 
As Kaufmann and Schneider (2004) concludes, the existing literature in this area of research has not specified a clear purpose for classifying intangibles and the categorization is considerate to be very abstract and the classes of intangibles are expansive.

\subsection{Considerations on measurement and recognition of intangible assets}

The topic of measurement in accounting generates sharp debates and research papers emphasis the advantages, disadvantages, similarities, usefulness, applicability of evaluation bases for structures used to point out the financial position, performance and changes in financial position of entities (Barth, 2006; Beatty et al., 1996; Elbannan \& Elbannan, 2015; Goh et al., 2015; Huang et al., 2013; Nobes, 2001; Plantin et al., 2008; Penman, 2006; Riedl \& Serafeim, 2011; Ryan, 2011; Wallison, 2008).

The presence of binary thresholds for the recognition of events is an omnipresent feature of extant accounting principles (Laux \& Stocken, 2018), consequently, IAS 38 Intangible assets, recognizes an item as an intangible asset when an entity demonstrates the item encounters: (a) the definition of an intangible asset; and (b) the recognition criteria (IAS 38, par. 21, 22). In the near future, IABS proposes the recognition process to be focused on relevance and fair representation (IASB, Project summary, 2018). To date, the probability criteria for recognition is always considered to be fulfilled for intangible assets that are acquired separately or in a business combination.

An entity is permitting to choose either the cost model or the revaluation model as its accounting policy. If an intangible asset is accounted using the revaluation model, all the other assets in its class shall also be accounted for using the same model, unless there is no active market for those assets (IAS 38, par. 74, 75).

If a professional attributes values to an element from financial reports, he/she take into the consideration the assumption of going concern and assigns potential of future benefits to an item (Walker, 2009). Some assets may be more accurately measured under fair value accounting, while others may be better measured under the historical cost basis (Pozen, 2009). It is evident from Ittner's (2008) research paper that majority of published papers are normative and provide little or no evidence on the benefits of these techniques applied in case of measurement of intangibles. Consequently, it is paramount for the valuators to group intangible assets on the basis of financial and non-financial measurements (Haskins and Sack, 2005; Ittner, 2008).

Basu and Waymire (2008) considers financial measurement of intangible assets epitome of accounting valuation. Although outside the company (or economy), 
money is not the only means to measure value, accounting is only endowed of recognizing resources and benefits which can be measured in monetary terms for any quality financial reporting for users.

On the other hand, some research papers enumerate reasons for recognition of intangibles as expenses: inexistence of an active market where to assess the value of them; many of intangibles are unique and, therefore, are not able for assessment; historical cost is not a reliable indicator of value; many of intangibles are interdependent one may have not value if another fails or the value assigned to the wrong asset create confusion about where the profit come from (Lonergan, 2009; Lonnqvist, 2002).

Accounting for research and development costs presents voluminous complexities: research and development costs are risky, with highly uncertain payoff and some accounting regulators consider they should be expensed, instead of capitalised. However, there is substantial indication to show that research and development costs outcome future economic benefits to entities (Hirschey \& Weygandt, 1985; Lev \& Sougiannis, 1996) and this suggests that the inclusion of them as a value creating asset would increase the value relevance of financial reports prepared for users (Elliot and Jacobson, 1991). Managers who are experienced in dealing with research and development costs are more careful about the projects they select for capitalisation to avoid future impairment decisions (Entwistle, 1999). The findings of research published by Bialek-Jaworska (2016) show that companies are more likely to capitalize research and development costs when issuing shares.

The difference between market value and book value of entities should not be explained by the existence of non-recognized intangibles in the financial reports, rather by changes in the value of non-accounting economic intangibles, such as improvements in government functioning and the impact of deregulation on intangibles and markets (Basu \& Waymire, 2008).

Therefore, there is a pressure on the accounting profession to make available a realistic appraisal of the value of intangible assets to respond in the best way the user's information needs (Ene at al., 2014).

\subsection{Considerations on value relevance of intangible assets}

Kadous et al. (2012) investigate whether financial reports' users consider relevance based on characteristics of reliability by conducting an experimental research. The findings point out that factors underlying reliability influence judgements of relevance, but features underlying relevance do not influence judgements of reliability. 
Value-relevance research papers consider the association between information items of interest and a stock price or financial measure of value, for instance, the market value of equity, stock returns or future earnings. Value-relevance tests are combined tests of relevance and reliability (Barth et al., 2001). The value relevance is conditional on the value reliability of the information about intangible assets in financial reporting to accomplish the users' requirements (Dahmash et al., 2009).

Aboody and Lev (1998) found that capitalised soft-wares are value relevant; capitalisation of software cost is associated with future earnings, further indicating that the capitalisation information is relevant to assisting investors make their economic decisions.

While not directly addressing the value-relevance topic, Boone and Raman (2001) examine the association between market liquidity and research and development costs recognized in Statement of Profit or Loss (expensed research and development cost). In case of non-capitalisation, the entities from a highly intensive research industry have a relatively high bid-ask spreads and low trading volumes, which lead to excessive costs of capital. Therefore, expenditures on intangibles are less reliable by definition compared with tangible assets.

Kallapur and Kwan (2004) show that there is a complementary relationship between the value relevance and value reliability of intangible asset information, precisely brands. The more reliable is its information about intangibles, the more value relevant is that information.

Dahmash et al. (2009) examine the value relevance and reliability of reported goodwill and identifiable intangible assets under Australian GAAP covering period from 1994 to 2003. They use the coefficients of reported goodwill and identifiable assets as the measurements of value relevance and value reliability. They argue that the coefficients of both unidentifiable intangibles (goodwill) and identifiable intangibles (such as brand names, master headings) are value relevant if they are significantly different to zero. These coefficients are also more reliable if they are not significantly different to one.

There is still a lack in approaches that evaluate the mechanism by which intangibles contribute to create value (Carlucci \& Schiuma, 2007), because of the idiosyncratic nature of these assets (Barney, 1991). Nevertheless, there is a consensus among academics that information about intangible assets is relevant to the business's value, and more information about intangibles require to be recognised; if not, then at least to be disclosed. 


\subsection{Considerations on international standard for financial reporting of intangible assets}

This paragraph will look through the history of IAS 38 Intangible assets since 1998, when the first IAS 38 have been issued. Even though IASB (IASC in 1998) started a work on developing a standard on intangible assets in 1989, it wasn't until 1993 that the project became the priority in the committee's agenda. After a steady effort of analysis of letters on exposure drafts (E50, E55, E60, E61), the board issued IAS 38. The main concern of comment letters referred to internally generated intangible assets. The Board rejected a proposal for an acceptable alternative to recognize expenditure on internally generated intangible assets as an expense immediately, even if it meets the requirement of an asset because the reason that "a free choice would undermine the comparability of financial statements efforts of the Board in recent years to reduce the number of alternative treatments in IAS" (BC, par. 24).

In 2004, the revised IAS 38 includes the considering about identifiability of intangibles assets if arise from a contractual or legal rights (IAS 38, par. 12.b), eliminates the mandatory impairment of intangibles with a useful life exceeding 20 years, and introduces the annually impairment under general rules provided by IAS 36 Impairment of assets.

In 2008, the IASB clarifies the circumstances in which an entity can recognise a prepayment asset for advertising or promotional expenditure. In 2009, the amendments refer to assets obtain in a business combination: an intangible asset acquired in a business combination might be separable, but only together with a related contract, identifiable asset or liability. In such cases, the acquirer recognizes the intangible asset separately from goodwill, but together with the related item (IAS 38, par. 36).

It is interesting to mention the intention of IASB to activate, in 2007, a project about identifiable intangibles, but it wasn't materialized.

\subsection{Considerations on disclosure of intangible assets}

Financial statements are intended to provide investors with information that is useful for making investment decisions. Disclosing information is enhancing comparability among companies and across reporting periods without compromising its usefulness (Conceptual Framework).

Since it has been so difficult to normalise intangibles, entities started to experiment themselves with different styles of reporting intangibles: graphs, tables, narratives. Voluntary disclosure has particularly on intangibles been quite extensive. The drivers of voluntary disclosure identified by Boesso and Kumar (2007) refers to management style, the existence and relevance of intangibles and market complexity. However, the method they used was to look for the argumentation given 
by management themselves in the annual reports and it can be discussed how valid the results are.

Skinner (2008) is arguing against capitalization or disclosure of more information on intangibles. He agrees with Lev (2001) on the negative impact of intangibles on cost of capital, but disagrees with his explanation that is related to the lack of information about intangibles, instead his explanation is based on riskiness of higher and unsustainable growth of business which led to less profits and lower probability to survive (Skinner, 2008).

Luft and Shields (2001) discuss the quality of information about intangibles is disclosed or capitalized. Barth et al. (2003) and Wyatt (2008) claim that disclosure is not an alternative that can substitute for recognition since the two different ways to provide information have different effects on the share prices.

\section{Research methodology}

The objective of this study is to carry out a review of accounting research literature in intangibles assets field. The present review of the intangibles literature covers academic papers published between 2000 and 2019 in highly influential journals (Bonner et al., 2006) from accounting and business field, and the Bucharest University of Economic Studies provides free access to papers published in these journals. The period for selection of papers starts with 2000, after the IASB approved IAS 38 Intangible assets. The ranking of journals is based on SJR score and $\mathrm{H}$ index score.

The Scimago Journal Rank (SJR) is based on the transfer of prestige from a journal to another one; such prestige is transferred through the references that a journal does to the rest of the journals and to itself, and $H$ index expresses the journal's number of articles $(h)$ that have received at least $h$ citations. It quantifies both journal scientific productivity and scientific impact and it is also applicable to scientists and countries (http://www.scimagojr.com). Based on Impact Factor (IF) data, the Journal Citation Reports published by Thomson Reuters provides yearly rankings of science and social science journals, in the subject categories relevant for the journal. Quartile rankings are therefore derived for each journal in each of its subject categories according to which quartile of the IF distribution the journal occupies for that subject category, as follows: Q1 denotes the top 25\% of the IF distribution, Q2 for middlehigh position (between top 50\% and top 25\%), Q3 middle-low position (top 75\% to top 50\%), and Q4 the lowest position (bottom 25\% of the IF distribution). Number of issues per year indicates possibility of a greater number of papers discussing the intangibles. (Table 1). 
Table 1. Journals

\begin{tabular}{|c|c|c|c|c|}
\hline Acronym & Journal & $\begin{array}{c}\text { SJR - } \\
\text { quartile }\end{array}$ & $H$ index & $\begin{array}{c}\text { No issue / } \\
\text { year }\end{array}$ \\
\hline JFE & $\begin{array}{l}\text { Journal of Financial } \\
\text { Economics }\end{array}$ & $12.489-\mathrm{Q} 1$ & 206 & 12 \\
\hline JAE & $\begin{array}{l}\text { Journal of Accounting } \\
\text { and Economics } \\
\text { Accounting. }\end{array}$ & $6.875-\mathrm{Q} 1$ & 122 & 4 \\
\hline AOS & $\begin{array}{l}\text { Organizations and } \\
\text { Society }\end{array}$ & $1.771-\mathrm{Q} 1$ & 110 & 8 \\
\hline JAL & $\begin{array}{l}\text { Journal of Accounting } \\
\text { Literature }\end{array}$ & $0.986-\mathrm{Q} 1$ & 6 & 2 \\
\hline $\mathrm{AF}$ & Accounting Forum & $0.932-\mathrm{Q} 1$ & 32 & 4 \\
\hline JAPP & $\begin{array}{l}\text { Journal of Accounting } \\
\text { and Public Policy }\end{array}$ & $0.910-\mathrm{Q} 2$ & 58 & 6 \\
\hline JAE & $\begin{array}{l}\text { Journal of Accounting } \\
\text { Education }\end{array}$ & $0.882-\mathrm{Q} 2$ & 28 & 4 \\
\hline $\mathrm{AE}$ & Accounting Education & $0.755-\mathrm{Q} 2$ & 21 & 4 \\
\hline IJA & $\begin{array}{l}\text { International Journal of } \\
\text { Accounting }\end{array}$ & $0.498-\mathrm{Q} 2$ & 45 & 4 \\
\hline IJAIS & $\begin{array}{l}\text { International Journal of } \\
\text { Accounting Information } \\
\text { Systems }\end{array}$ & $0.399-\mathrm{Q} 2$ & 42 & 4 \\
\hline $\mathrm{RC}$ & $\begin{array}{l}\text { Revista de Contabilidad - } \\
\text { Spanish Accounting } \\
\text { Review } \\
\text { Journal of Contemporary }\end{array}$ & $0.345-\mathrm{Q} 3$ & 10 & 2 \\
\hline JCAE & $\begin{array}{l}\text { Accounting and } \\
\text { Economics }\end{array}$ & $0.326-\mathrm{Q} 3$ & 12 & 3 \\
\hline IJAIM & $\begin{array}{l}\text { International Journal of } \\
\text { Accounting and } \\
\text { Information Management } \\
\text { Journal of International }\end{array}$ & $0.275-\mathrm{Q} 3$ & 14 & 4 \\
\hline JIAAT & $\begin{array}{l}\text { Accounting, Auditing and } \\
\text { Taxation }\end{array}$ & $0.265-\mathrm{Q} 3$ & 33 & 4 \\
\hline IJAAPE & $\begin{array}{l}\text { International Journal of } \\
\text { Accounting, Auditing and } \\
\text { Performance Evaluation }\end{array}$ & $0.140-\mathrm{Q} 4$ & 12 & 4 \\
\hline
\end{tabular}

These databases were examined with the purpose of finding papers having as research topic intangibles or similar objects (Nobes, 2018); the research was based on occurrence of term "intangible" in title, abstract, keywords. The archival analysis of 15 journals and 76 papers resulted in 36 papers which fulfil the requested features: published later than 2000 and contain the term intangible in title or abstract or keyword section. The reviewing procedure of the selected research papers for the 
purpose of current work follows Brown and Jones (2015) and Lungu et al. (2016) model used to analyse contemporary financial accounting topics.

The selected papers were classified based on (1) year of publishing to identify the impact of issued IAS 38 on academic research and the intensity of research after its publication and on (2) topic discussed to identify the categories of intangible considered. Therefore, the content analysis of papers is primary methodology research used in the present investigation (Steenkamp \& Northcott, 2007).

The selected papers are considered as follows: recognition and measurements (22\%), intellectual capital (22\%), relationship between intangibles and other business financial indicator (17\%), analysis of a specific element from intangibles (17\%), disclosure of intangibles (11\%), information technology (6\%), and goodwill (6\%).

\section{Analysis of results and discussion}

The research on the topic of intangibles continuously motivates authors to analyse and investigate on them; the greater number of papers in association with our topic is published in International Journal of Accounting ( 7 selected papers out of 15 reviewed papers), followed by Journal of Financial Economics, Accounting Forum and Journal of Contemporary Accounting \& Economics ( 5 selected papers out of 12, 6 respectively 5 reviewed papers), and then, Journal of International Accounting Auditing \& Taxation, Journal of Accounting and Public Policy and Accounting, Organizations and Society ( 3 selected papers out of 6, 5 and respectively 4 reviewed papers).

Four journals didn't publish any paper in association with this paper topic, namely: Journal of Accounting Literature, Accounting Education, International Journal of Accounting and Information Management, and International Journal of Accounting, Auditing and Performance Evaluation. The distribution of published research papers adjacent to intangibles is presented in Table 2 .

Table 2. Structure of selected papers

\begin{tabular}{lrrr}
\hline \multicolumn{1}{c}{ Journal } & $\begin{array}{c}\text { No of papers } \\
\text { reviewed }\end{array}$ & $\begin{array}{c}\text { No of papers } \\
\text { selected }\end{array}$ & $\begin{array}{c}\text { Selection } \\
\text { rate of } \\
\text { papers }\end{array}$ \\
\hline Accounting Forum & 6 & 5 & $83 \%$ \\
Accounting, Organizations and Society & 4 & 3 & $75 \%$ \\
International Journal of Accounting & 1 & 1 & $100 \%$ \\
Information Systems & 14 & 1 & $7 \%$ \\
Journal of Accounting and Economics & 5 & 3 & $60 \%$ \\
Journal of Accounting and Public Policy & 2 & 1 & $50 \%$ \\
Journal of Accounting Education & & &
\end{tabular}

Vol. 18, No. 2 


\begin{tabular}{lccr}
\hline \multicolumn{1}{c}{ Journal } & $\begin{array}{c}\text { No of papers } \\
\text { reviewed }\end{array}$ & $\begin{array}{c}\text { No of papers } \\
\text { selected }\end{array}$ & $\begin{array}{c}\text { Selection } \\
\text { rate of } \\
\text { papers }\end{array}$ \\
\hline $\begin{array}{l}\text { Journal of Contemporary Accounting \& } \\
\text { Economics }\end{array}$ & 5 & 5 & $100 \%$ \\
$\begin{array}{l}\text { Journal of Financial Economics } \\
\text { Journal of International Accounting Auditing }\end{array}$ & 12 & 5 & $42 \%$ \\
$\begin{array}{l}\text { \& Taxation } \\
\text { Revista de Contabilidad - Spanish Accounting }\end{array}$ & 6 & 3 & $50 \%$ \\
$\begin{array}{l}\text { Review } \\
\text { The International Journal of Accounting }\end{array}$ & 3 & 2 & $67 \%$ \\
\hline Total & 15 & 7 & $47 \%$ \\
\hline
\end{tabular}

The distribution of papers across years highlights an average of 2 papers / year (mean $=2.05$, std $=1.16$ ). For the selected period of time and journal, we can conclude there is a constant interest in writing and accepting papers regarding intangible assets; additional, year 2013 is a prolific year in terms of number of papers published in association with this research' theme; it is identified five papers. So far, for year 2019 (March, 2019), one work concerning intangibles was acknowledged.

Table 3. Distribution of published papers per year

\begin{tabular}{rrr}
\hline Year of publication & No of papers published \\
\hline 2000 & 1 \\
2001 & 4 \\
2002 & 2 \\
2004 & 1 \\
2005 & 1 \\
2006 & 2 \\
2008 & 3 \\
2009 & 1 \\
2010 & 2 \\
2011 & 3 \\
2012 & 2 \\
& 2013 & 5 \\
2014 & 2 \\
& 2015 & 1 \\
& 2016 & 1 \\
& 2017 & 1 \\
2018 & 3 \\
& $2019 *$ & 1 \\
& & 36 \\
\hline Total & & 1 \\
\hline
\end{tabular}


The waves in academic works published during 2000 and 2019 is related to changes and amendments for accounting standard IAS 38. Based on inflexion-point theory, Ienciu and Matis (2014) prepared an analysis of evolution of IAS 38 and identified 6 inflexion points. The moments selected by Ienciu and Matis (2014) as references were used to group the selected paper of current research (Table 4).

Table 4. Collection of papers group by period

\begin{tabular}{|c|c|c|}
\hline Period & $\begin{array}{c}\text { No of } \\
\text { papers }\end{array}$ & Comments about IAS 38 \\
\hline 1998-2004 & 8 & $\begin{array}{l}1998 \text { - Issue of IAS } 38 \\
\text { Application of IAS } 38\end{array}$ \\
\hline 2004-2008 & 6 & $\begin{array}{l}\text { IAS } 38 \text { applies to intangible assets acquired in business combi- } \\
\text { nations occurring on or after } 31 \text { March } 2004 \text {, or otherwise to } \\
\text { other intangible assets for annual periods beginning on or after } \\
31 \text { March } 2004\end{array}$ \\
\hline 2008-2009 & 1 & $\begin{array}{l}\text { Amended by Improvements to IFRSs (advertising and promo- } \\
\text { tional activities, units of production method of amortisation) }\end{array}$ \\
\hline $2009-2013$ & 12 & $\begin{array}{l}\text { Amended by Improvements to IFRSs (measurement of intangi- } \\
\text { ble assets in business combinations) }\end{array}$ \\
\hline 2013-2014 & 2 & $\begin{array}{l}\text { Amended by Annual Improvements to IFRSs } 2010-2012 \text { Cycle } \\
\text { (proportionate restatement of accumulated depreciation under } \\
\text { the revaluation method) }\end{array}$ \\
\hline $\begin{array}{l}\text { Later than } \\
\quad 2014\end{array}$ & 7 & $\begin{array}{l}\text { Amended by Clarification of Acceptable Methods of Deprecia- } \\
\text { tion and Amortization (Amendments to IAS } 16 \text { and IAS 38) }\end{array}$ \\
\hline
\end{tabular}

The goal of classification is to meet the expectation of an analytical investigation of content of papers in respect to intangible (Nobes, 2018), consequently, a more refine classification was applied (Table 5).

Table 5. Collection of papers group by well-structured topic

\begin{tabular}{lcc}
\hline \multicolumn{1}{c}{ Proposed Clusters } & No of papers & Weights \\
\hline Intangible assets - recognition and measurement & 8 & $22 \%$ \\
Intangible assets - human (intellectual) capital & 8 & $22 \%$ \\
Intangible assets - relationship with other business & 6 & $17 \%$ \\
indicator & 6 & $17 \%$ \\
Intangible assets - specific element & 4 & $11 \%$ \\
Intangible assets - disclosure & 2 & $6 \%$ \\
Intangible assets - technological assets & 2 & $6 \%$ \\
Goodwill & $\mathbf{3 6}$ & $\mathbf{1 0 0 \%}$ \\
\hline Total & & \\
\hline
\end{tabular}




\subsection{Findings regarding the cluster Intangible assets - recognition and measurement}

The longstanding debate on the recognition and measuring in accounting, in general, (Chambers, 1997; Clausen \& Hirth, 2016; Corrado et al. 2009; ICAEW, 2006; Lin et al., 2017; Ryan et al., 2002; Sadowska \& Lulek, 2016; Sullivan \& Wurzer, 2009; Staubus, 2004; Willet, 1988) is surpassed by the more controversially recognition and measuring for intangibles.

As Johanson et al. (2001) emphasize, one of the main difficulties when it comes to managing intangibles is the lack of reliable financial information about them. Ross and Ross (1997) and Liebowitz and Suen (2000) state that to be able to better manage a resource, it is necessary to be able to measure it.

Intangible assets have some unique characteristics which are relevant when assessing whether they should be recognized as resource or expense: (1) they have few or no alternative uses as many intangibles are firm-specific and difficult to utilize for others; (2) problems with, or even lack of, separability as many intangibles only have value in combination with tangible assets; (3) difficulties with determining whether the asset originally recorded is being maintained or whether a new asset is being gradually substituted for it; and (4) greater uncertainty of whether their costs will generate future economic benefits (Huegh-Krohn \& Knivsfla, 2000).

Accounting theory and professionals recognize the fact that these characteristics may, in particular circumstances, demand a different, more prudent treatment of intangible resources, especially because the recoverable value of intangibles is less reliable than for other assets (Eckstein, 2004; Garcia-Merino, 2011; Goodwin et al., 2008; Huegh-Krohn \& Knivsfla, 2000)

The social construction of accounting certificates the interpretation of criteria for assets recognition with the purpose of preparing trustworthy financial reports useful in decision making process and forecasting the potential of businesses to create value for a wide range of stakeholders.

Retrospective view on assets definition proposed by IASB highlights the changes over time from "resource controlled ... from which future economic benefits are expected to inflow" (IASB 2001, CF, par. 49) to "present economic resource to which the entity presently has an enforceable right (IASB, 2007) to proposed clarification of an economic resource as "a right that has the potential to produce economic benefits" (IASB, 2018). The switch is from an economic output standpoint - future economic benefits to an economic input standpoint - present economic resource (El-Tawy, 2012). 
The proficiency of intangibles to create future benefits comes with vulnerability and susceptibility which derives from their unique attributes: partial excludability, inherently high risk, and non-marketability (Lev, 2002). Moreover, intangible resources are not rewarding and productive in themselves, their value is obtained in conjunction with other resources and within a work group and with a specific objective (Garcia-Merino, 2011), and associated to a specific competitive context, which determines the value of an entity (Grant, 1991).

A comparison between accounting recognition and measurement of intangible assets formulated in Scandinavian accounting standards, UK standards (ASB), USA standards (GAAP) and international standards (IAS) reveals insignificant differences in respect to intangibles presumably because they are all dominated by the AngloSaxon accounting practice, focusing on the capital market as the primary users of financial statement information (Huegh-Krohn \& Knivsfla, 2000): capitalization with amortization and impairment test (USA, APB 17), predominantly expensing research and development costs, with option of capitalization only when they meet very stringent criteria then amortized (UK, SSAP 13), capitalization of intangibles, but the tax deduction encourages entities to expense these costs (Scandinavian countries, European Union Directives, $4^{\text {th }}$ Directive and $7^{\text {th }}$ Directive). Nevertheless, the less reluctant attitude of continental European countries towards recognition of intangible assets in statement financial position is relying on credit-oriented economy where is important to signal the value of collateral to financial creditors (merely, banks) in opposition to market-oriented economy where is important to signal value to investors.

At international level, IASB overrules the recognition as assets of internally generated, as goodwill, brands, mastheads, publishing titles, customer lists and items of similar substance (IAS 38). The international accounting standard (IAS 38) preserves a market basis in measurement of intangibles that links informational reliability to market-based estimates of value. Therefore, this accounting standard assumes that market quotations are reliable and refuses to recognize the value of assets through measurement of the expenditures for resources that lack a proper market basis, although the international accounting standards-setting body has acknowledged that an "entity's costing systems can often measure reliably the cost of generating an intangible asset internally, such as salary and other expenditure incurred" (IAS 38, par. 62). By contrast, the entity-specific basis of accounting, including a pure historical cost accounting system, which is able to capitalize and amortize these expenditures as depreciable assets in harmony with specific conventions at the entity, industry or economy levels (Biondi \& Reberioux, 2012). Improvements in historical cost accounting systems may be promising because historical costs have the important cognitive advantage of being secure in most cases by actual transactions that can be tracked through time and that are easier to audit. 
To bridge the hypothetically increasing information gap caused by the lack of intangible asset recognition, Huegh-Krohn and Knivsfla (2000) analyse two nonexclusive ways of combining matching principle with prudence principle: (1) capitalization with amortization and impairment tests, and (2) expensing with conditional reversion. These alternatives give better information signals to financial statement users and thereby increase the value-relevance of financial statements. They draw attention upon on misinterpretation of their proposal: "do not start capitalizing doubtful intangible assets" (Huegh-Krohn \& Knivsfla, 2000), but they require that previously expensed intangibles should be capitalized in a later period when the criteria for asset recognition are met (Huegh-Krohn \& Knivsfla, 2000; Lev \& Zarowin, 1999).

The revaluation model for intangibles assets is investigated by Yao et al. (2015) in correlation with audit fees; their research emphasizes that fair value of assets used in revaluation model conducts to higher audit fees by either reducing audit efficiency or increasing audit risk due to amplified agency problems.

In order to get accounting standards accepted, standard-setters have to carefully balance the various considerations affecting the relevance, faithful representation and reliability and, hence, informativeness of financial statements. Additionally, they have to take into consideration the interests of all participants from business: reporting entities, users, financial analysts. The entities that are more interested in the valuation of their intangibles for external reasons need to provide information to stakeholders about their ability to generate future income (Garcia-Merino et al., 2011).

With the intention of assigning value to intangible assets, they should generate some measurable amount of economic benefit to the owner, such as incremental turnover or earnings (pricing, volume and better delivery, amongst others), cost savings (process economies and marketing cost savings) and increased market share or visibility. Possessors exploit intangibles either in their own business (direct use) or through a license fee or royalty (indirect use).

All the approaches concerning recognition of intangibles notice the complexity of intangibles, weaknesses of accounting' instruments or inaccurate or lack of models for best practices (Jeny \& Moldoveanu, 2016; Martin-Olivier \& Salas-Fumas, 2007).

\subsection{Findings regarding the cluster Intangible assets as intellectual capital}

The goal of measuring intellectual capital is to attempt to enlighten the difference between the accounting and market value of the company, as well as to discover those unknown values that mostly contribute to the achievement of business goals and the creation of continuous value added. 
Based on conventional theory, non-accounting information, such as some information about intangibles, may not be price-sensitive information; yet it is still important, and even more important, in certain contexts, than accounting on tangible assets, in affecting investment decision making (Chen et al., 2014).

Chen et al. (2014) discover that knowledge and social contexts in the market for information play a significant role and influence the information changes, as well as analysts' behaviour and perceptions; the knowledge and information of financial creditors, analysts and other market actors have a strong complementary nature, being considered a "mirror image" because of their common interest in business model.

Abhayawansa et al. (2015) find that sell-side analysts make extensive use of intellectual capital information in developing their opinions of companies' future projections, in formulating valuation model inputs, in developing price and investment recommendations, and in analyst-client communications.

The relationship of intangibles assets with employees' compensation contracts is explored by Alhaj-Ismail et al. (2019), Edmans (2011), and Sun and Xiaolan (2018); their papers underline the significantly positive association between the above mentioned variables. The inexistence of instruments to recognize in financial reports the employees' satisfaction, although managers are able to credibly communicate the value of their intangibles creates room for hesitations in investors' decision making process (Edmans, 2011). This conclusion is in line with Ramirez-Corcoles and Ponces's (2013) investigation, where they revealed deficiencies of accounting's mechanisms for identification and measurement of intangible elements as the main reason for not disclosing information on intellectual capital, with effects on transparency, image and reputation of entity and a drive of explaining the disparity between market value and book value of entities (Mouritsen et al., 2001) or to create opportunities for uninformative disclosure behaviour (Skinner, 2008).

The Sun and Xiaolan's (2018) research is preparing an in-depth analysis and observe the negative correlation between intangible capital and borrowings (debts) or constant equity issuance, even if, intangible capital can be used as collateral to "borrow" from employees.

Theories advanced by Barthes (1977) and Bourdieu (1986) with reference to the visual images are applied by Davison (2010) to glorify pictures as powerful tools for communicating messages regarding all aspects of organisations and to criticise the deficient accounting framework for intangibles which leads users of financial reports to seek enlightenment beyond the quantitative data offered in the financial statements. The existence of intangibles is systematically solidified noticeable through the unrestricted pictures in annual reports, particularly by companies with 
large values for intangibles, brands essentially (Davison \& Skerratt, 2007); the transformation of intellectual capital from invisibility or nothingness into visibility or somethingness is often described as networks where visualisations is as important as stories and numbers (Davison, 2010; Mouritsen et al., 2001).

The corporations' intellectual capital should be managed, and therefore, Radenovic and Krstic (2017) enumerate recommendations to cope with by identifying and assessing the role of knowledge as a resource for the business as input, process and output.

\subsection{Findings regarding the cluster Intangible assets - relationship with other business indicator}

Intangible assets are long lived assets used in the production of goods and services. They lack physical properties and represent legal rights or competitive advantages (a package of rights) developed or acquired. Misunderstanding the nature of intangibles assets can have unpleasant consequences for investors and stakeholders (Daum, 2003).

The quality of earnings, measured through volatility, relevance and, matching may decrease in case of increase of intangible assets controlled as resources by entities, because their uncertainty about future economic benefits leading to an increased volatility and a lower quality in applying matching concept (Srivastava, 2014). Similar results have obtained Kothari et al. (2002). The professional-judgment and professional-experience applied for intangibles, with options between recognition in statement of financial position or in statement of comprehensive income or disclosure in notes, is analysed by Goodwin and Ahmed (2006). The value relevance of earnings is lower for entities which do not recognized intangible assets as research and development costs or deferred costs in balance sheet; their results are based on a sample of 13,000 Australian firm-year observations covering 25 years from 1975 to 2000 .

Moreover, the high level of un-recognized intangible assets relies significantly less often on accounting rate-of-return measures compared to earnings alone, in executive bonuses plans (Krolick, 2005). The conclusion is constructed on a sample of financial data extracted from 376 entities involved in creating and employing brand equity, patents and copy-rights or human capital, between 1987 and 1993. To measure the investments in intangibles, the ratio book/equity ratio is adopted.

An interesting association is between intangibles and transfer pricing policies and it is investigated by Borkowski (2001) and Richardson et al. (2013). While the role of transfer price is to minimize the tax burden and increase the profits, Richardson et al. (2013) provide evidence that intangibles increase the aggressiveness in negotiations of transfer prices; their work proposes a regression model to measure 
the aggressiveness of transfer pricing based on entity size, leverage, intangible assets and multi-nationality for a sample of 183 listed Australian entities and discover a strong positive relationship between aggressiveness index and intangibles. Multinationality and transfer prices are addressed by Borkowski (2001) in assessing the transfer prices of intangible properties by US transnational corporations compared to Canada, Germany, Japan UK, countries where US corporations have subsidiaries; in this paper Borkowski (2001) identified that $25 \%$ of respondents uses a nonaccepted either OECD or US evaluation method for intangible property and linked this policy with: reliance on historical practices or strong country-specific rules and penalties.

Multi-national entities arise from mergers and acquisitions transaction; Levine (2017) determines that, in a new model of mergers, distinct from neoclassical model, the entities with high value of intangibles, high value of productivity are not targets for acquisitions, suggesting they have quality projects and opportunities for internal growth. In these cases, the acquirers engage in only capital investments. However, the degree to which tangible or intangible assets are the motive for acquisition vary across industries.

\subsection{Findings regarding the cluster Intangible assets - specific element}

This cluster includes research papers addressing a specific item classified as intangible asset.

Anagnostopoulou and Levis (2008) investigate the research and development costs reported by a large dataset of UK entities covering the period 1990-2003 and concluded that research and development costs have a successful economic outcome reflected in the persistence of the growth rates of operating performance. Anagnostopoulou and Levis' s (2008) academic work confirms that highest research and development costs in businesses as IT hardware and pharmaceuticals with percentages close to $80 \%$ of firm-year observations, electronics and engineering with high rates of research and development activity with $69.5 \%$ and $54.5 \%$, respectively, software and computer services companies with research and development $54.7 \%$, earn higher risk-adjusted excess returns than the sample median return more consistently, compared to lower research and development costs intensity industry, as well as zero - research and development costs. Additionally, Anagnostopoulou and Levis (2008) certify that research and development costs are positively associated with persistent excess stock market returns, for one year after another, for a consecutive number of years, after controlling for risk differences among firms arising from firm size and the book-to-market factor.

Stolowy et al. (2001) and Larkin (2013) focus on definition, recognition, measurement, and influence of brand on businesses. Researches in the marketing 
field demonstrate positive consumers' evaluation of brands in association with higher loyalty and larger purchase probabilities (Bronnenberg, 2009; Court, 2009; Dodds, et al., 1991; Ishak \& Ghani, 2013; Malik et al., 2013; Murthi \& Srinivasan, 1999; Rao \& Monroe, 1989; Starr \& Rubinson, 1978).

Similarly, Stolowy et al. (2001) highlight the favourable consequences of brands on businesses and consider them a key management responsibility because (1) maximize the shareholders' value; (2) increase the estimation of the value of a company in the context of mergers and acquisitions, and (3) determine the value of royalties for brands. The inherently issue of valuing brands is addressed in context of litigations: the more valuable they are perceived the more companies are prepared to spend, to protect, and defend their values.

Larkin (2013) demonstrates that positive perception of corporations' products reduces forward-looking volatility of cash flows, and insulates businesses during periods of recession. The lower riskiness associated with strong brand increases the probability that entities will meet their future financial obligations, and lightens financial frictions, allowing to have higher levels of debt and smaller cash cushions.

In close-fitting association with brands are advertising expenditure. Keller (2008) indicates that advertising promotes brand equity, which in turn generates financial value through enhanced cash flows attributable to customer loyalty, increased marketing efficiency, brand extensions, and higher margins. Despite the substantial economic importance of advertising expenditures in constructing brand equity and its prospective impact on future cash flows, not much attention has been given to the accounting treatment and disclosure requirements of advertising expenditures. In this context, Shah et al. (2009) study if major media advertising expenditures, that are publicly available at cost, have value relevance for businesses, by using a valuationmodel approach on data extracted from financial reports of UK entities for period between $1990-1998$. The conclusion of research is that advertising expenditure are positively associated with market value. When the firms are analysed by size, there appears to be an insignificant difference in the value relevance of these expenditures among different sizes of firms. When the sample is divided into manufacturing and non-manufacturing corporations, the value relevance is only present for nonmanufacturing firms.

As an essential part of companies' intangible assets, patents and patent statistics have long been scrutinized by researchers (Hall et al., 2005; Wang et al., 2010;). In recent years, patent's assessment has been used not only to evaluate company innovation level or competition status within a given industry, but also in applied for patent portfolio analysis as part of corporate strategy. Garcia et al. (2010) propose an evaluation method for patent portfolio based on multi-criteria analysis to express the relative importance of the patents. Garcia et al.'s (2010) paper offers an option to 
rank companies according to the importance of their patents and does not claim to solve the applied problem of valuing patent portfolios from a corporate perspective.

The digitalisation of economies creates room for new intangibles, as cybersecurity awareness (Berkman et al., 2018). The research paper conducted by Berkman et al. (2018) discuss the value relevance of cybersecurity awareness and its association with market value. The research develops a cybersecurity awareness score based on textual analysis of cyber-related disclosures for a sample of 2264 firms from USA and 9677 observations, using a comprehensive dictionary. They illustrated that cybersecurity awareness, tone of cyber-related disclosures and other proxies of cybersecurity awareness, namely IT governance and prior experience with cyber breaches are all positively associated with market valuations. This evidence of capital market effects of cybersecurity awareness and tone of cyber-related disclosures should be particular interest to management, and, rather than providing information about their vulnerabilities, corporations should disclose information related to strategies for mitigating cybersecurity risks.

\subsection{Findings regarding the cluster Disclosure of intangible assets}

Disclosure is a multidimensional concept (Beattie et al.,2004) that integrates various aspects, namely, size, leverage, profitability and listing status of entity (Jensen \& Meckling, 1976) or adoption of IFRS/GAAP, industry type, price-to-book ratio, legal system (Kang \& Gray, 2011), contributes to a better understanding of elements recognized in financial reports using narrative presentation, and is the subject of inherent difficulty to the measure it, in terms of quantity and quality (Healy \& Palepu, 2001; Jeny \& Moldoveanu, 2016).

The users of financial reports have right to be informed through different disclosures of how a corporation's operations impact them (Deegan, 2000). On the other hand, legitimacy theory (Neu et al., 1998) suggests that companies have to consider not only the rights of investors to identified signals for investments' decisions (Curmei et al., 2018), but also the overall community.

Conceptual Framework for Financial Reporting (2010, par. 4.37) states that recognition is the process of incorporating in financial reports an item that meets the definition of an element and satisfies the criteria for recognition. It involves the portrayal of the item in words and by a monetary amount. Additionally, IAS 1 Presentation of financial statements includes Notes, which provides narrative descriptions, as a primary component of a complete set of financial reports. Voluntary and non-voluntary disclosure of financial information is determined by materiality, cost - benefits constraint (CF, 2010), and personality of accounting professionals (Kumar, 2013). 
While the prominence of intangible assets in creating and maintaining corporate value have been widely accepted, financial reporting frameworks do not capture many of these value drivers (Jenkins \& Upton, 2001; Lev \& Zarowin, 1999; Upton, 2001) due to the "non-physical" nature and the subsequent uncertainties associated with their "future economic benefits".

To overcome the negative consequences of non-recognition of intangibles, disclosure is the solution and is able to mitigate the adverse selection problem in the capital market by reducing the asymmetry between corporation and investors (Zeghal \& Maaloul, 2011). Voluntary disclosure of information about intangible assets provided by a sample of UK and international companies between 2001 and 2007 motivates Zeghal and Maaloul (2001) to consider disclosure as a process to communicate information that are not recognized in the financial statements (Zeghal \& Maaloul, 2001). Communication with stakeholders is realized through annual financial reports or internet (Trabelsi et al., 2008).

Kang and Gray (2011) and Kumar (2013) investigate the voluntary disclosure of intangible assets by proposing an index based using 12 variables (size of entity, ownership structure, leverage, price-to-book ratio, recognition of intangibles as \% from total assets, age of entity, economic policy risk index, legal system risk index, regulation risk index and dummies GAAP/IFRS (1) or national regulations (0), listed status (1) or non-listed entity and intensive industry (1) or low intensive industry (0)) respectively, 8 variables (size of entity, ownership concentration, individualism, power distance, foreign sales, leverage, and dummies GAAP/IFRS (1) or national regulations (0), non-financial industry (1) or other (0) and high-tech industry (1) or other $(0)$ ). Both researches conclude that size, type of industry, international standards, listing status are positively correlated with voluntary disclosure of information about intangible assets, negative correlation with leverage and mixt results concerning the other variables. An interesting observation is that entities' country specific factors are significantly associated with level of disclosure as Kang and Gray (2011) revealed through economic policy risk index, legal system risk index, regulation risk index and Kumar (2013) through individualism ${ }^{2}$ and power distance ${ }^{3}$.

Regardless the strategy adopted to provide information about company: annual reports or via websites, simply, the managers disclose more information when they have good news or expect an increase in profits (Enache at al., 2017; Lev \& Penman, 1990; Rappaport, 2006; Singhvi \& Desai, 1971; Trabelsi et al., 2008; Wallace et al., 1994).

\footnotetext{
${ }^{2}$ Hofstede's cultural dimensions (1980)

${ }^{3}$ Hofstede's cultural dimensions (1980)
} 


\subsection{Findings regarding the cluster Intangible assets - technological assets}

According to Lev (2001), two characteristics of today's economy are dominant: a more intense competitive business environment and the exponential progress of information technologies. The economies of scale which underpinned traditional production activities where tangible assets were significant, is shattered. Investments in financial and intangible assets result in sustainable competitive advantage and intellectual capital is now the source of competitive advantages (Hamel \& Prahalad, 1994).

Despite the fact numerous studies that find evidence of the positive relationship between investment in intangibles and the value creation of the company (Engstrom et al., 2003; Firer \& Williams, 2003; Prieto \& Revilla, 2006; Riahi-Belkaoui, 2003; Saenz, 2005; Tan et al., 2007), Dehning et al. (2006) demonstrated that, as the level of investments in information technology increases, information risk and uncertainty about future earnings increase as well, because of difficulty translating the benefits of investing into IT into prospect incomes. Their research is based on over 1000 firms form IT industry which disclose information about IT investments.

The findings of Dehning et al. (2006) are totally opposite with results of Lin (2012), which states that in a neoclassical model with endogenous technological progress driven by research and development costs, the expected marginal earnings of physical capital rise and the marginal costs of physical capital reduce.

\subsection{Findings regarding the cluster Goodwill}

Accounting for goodwill has historically been the subject of much controversy among scholars and policy makers, and has been associated with considerable variation in accounting practice across countries over time (Bloom, 2008, 2009). Complexity of goodwill originates from its components: measurement conservatism (fair value in excess of book value), recognition conservatism (fair value of items non-recognised by acquirer), going-concern confidence as core of goodwill (possibility of higher return on assets), synergy captured by goodwill (the new mix of net assets of acquirer and target creates higher returns), consideration payments and overpayments or underpayments for target (IFRS 3 - BC 313; Johnson \& Petrone, 1998; Johansson et al., 2016).

Hirschey and Richardson (2002), using event research method, for a sample of 80 observations about goodwill write-off announcement made by US entities distributed across 32 industries, between 1992 and 1996, reported that accounting goodwill numbers do embody aspects necessary for asset recognition on the financial statements of businesses. Like balance-sheet models that show positive valuation effects of accounting goodwill numbers, negative stock-price effects tied to goodwill 
write-off decisions indicate that these data capture a significant aspect of the intangible dimension of firm value. Negative and statistically significant stock-price reactions tied to goodwill write-off decisions also suggests that accounting theory and practice is adept at identifying when such intangible assets are impaired.

In 2005, IASB issues a new standard for business combination (IFRS 3) replacing IAS 22. IFRS 3 replaces the two-component (dual) approach (amortization with an additional impairment test when required) with an impairment-only approach (nonamortization but with annual, or more frequent if necessary, impairment tests).

Johansson et al. (2016) state that representation of goodwill on the statement of financial position and the effectiveness of goodwill impairment losses as a signal of acquisition, the performance, in terms of relevance, should improve.

\section{Conclusion and further research}

This exploratory paper contains a literature review on the financial accounting aspects on intangibles, definition, measurement, recognition, disclosure and reporting to internal and external stakeholders. It covers the latest 19 years (2000 2019) of the literature; previous academic works are considered relevant and reference to them is respectful. The archival analysis was conducted and analysis of 15 journals and 76 papers resulted in 36 papers which fulfil the requested features: published after 2000 and contain the word intangible in title, or abstract or keyword section.

The paper investigates the intangible assets in respect to: (1) how IASB reviewed the standard in respect to intangible assets, (2) difficulties in defining intangibles, (3) what philosophies were applied in measurement and recognition of intangibles, (4) what element classified as intangible assets impact the business performance, (5) how should accounting professional should display information about intangible assets, and (6) how investors feel about intangibles when they decide to invest into a business.

The selected papers are considered as follows: recognition and measurements (22\%), intellectual capital (22\%), relationship between intangibles and other business financial indicator (17\%), analysis of a specific element from intangibles (17\%), disclosure of intangibles (11\%), information technology (6\%), and goodwill (6\%).

The economy of the business involves intangible resources that relate to idiosyncratic productive processes specific to each firm. Intangibles contribute to define the firm as a specific economic environment that is different and not replicable by the market (Biondi \& Reberioux, 2012). Barney (1991) justifies that intangible resources must be valuable, rare, inimitable and non-substituible. 
The market basis of accounting is increasingly advocated for the accounting and reporting of intangibles (Uzma, 2011; Wyatt, 2005). The "transparency" of the business firm is proclaimed as a mantra. Accordingly, a reference to market prices is considered to be the best solution for the acknowledged difficulties of recognition and measurement of intangibles. This implies that financial accounting and reporting should take market prices as references to recognize intangibles in financial statements and disclosures (Biondi \& Reberioux, 2012). The imminent occurrence of new intangibles in business will rise more difficulties in recognition, measurement, disclosure. The non-financial reports may undertake the financial lacunas (Wyatt, 2008).

The status-quo of intangibles revealed in this work will lead to further research project which will broaden the number of journals and research papers publish to assure a deeper analysis of intangibles (1) to identify philosophies applied in measurement and recognition of intangibles; (2) to discover how accounting professional should display information about intangible assets, financially and nonfinancially and the consequences of recognition - non-recognition, disclosure - nondisclosure of intangibles on relevance and reliability of accounting reports; (3) to develop a theoretical framework for connecting intangibles with organizational theories and accounting behaviour; (4) and to bridge the accounting with other disciplines to put in a nutshell the benefits of intangibles.

We are witnessing one of the most critical moment in history of accounting: based on knowledge and technology - intensive economy imposes new guidelines for recognition, measurement, disclosure and reporting of intangibles to ensure to foster the quality of financial reporting and reliability of accounting information for decision-making process.

This research opens up opportunities for further developments into a multidisciplinary analysis to understand the role of intangibles assets in contemporary economies and to articulate policies to foster their expansion and use in business.

\section{References}

Abdolmohammadi, M.J. (2005) "Intellectual capital disclosure and market capitalization", Journal of Intellectual Capital, vol. 6, no. 3: 397-416

Abeysekera, I. (2016) "Does the classification of intangibles matter? An equivalence testing", Advances in Accounting, incorporating Advances in International Accounting, no. 35: 135-142

Abhayawansa, S., Aleksanyan, M. \& Bahtsevanoglou, J. (2015) "The use of intellectual capital information by sell-side analysts in company valuation", Accounting and Business Research, vol. 45, no. 3: 279-306 
Aboody, D. \& Lev, B. (2000) "Information asymmetry, R\&D, and insider gains", The Journal of Finance, vol. 55, no. 6: 2747-2766

Akerlof, G. (1970) "The market for "lemons": Quality uncertainty and the market mechanism", The Quarterly Journal of Economics, no. 90: 629-650

Alhaj-Ismail, A., Adwan, S. \& Stittle, J. (2019) "Share-option based compensation expense, shareholder returns and financial crisis", Journal of Contemporary Accounting \& Economics, vol. 15: 20-35

Anagnostopoulou, S.C. \& Levis, M. (2008) "R \& D and performance persistence: Evidence from the United Kingdom", International Journal of Accounting, no. 43: $293-320$

Andriessen, Daniel (2004) Making Sense of Intellectual Capital- Designing a Method for the Valuation of Intangibles, Oxford: Elsevier

Barney, J.B. (1991) "Firm resources and sustained competitive advantage", Journal of Management, vol. 17, no. 1: 99-120

Barth, M. \& Clinch, G. (1996) "International accounting differences and their relation to share prices: evidence from UK, Australian, and Canadian Firms", Contemporary Accounting Research, vol. 13, no. 1: 135-170

Barth, M. (2000) "Valuation-based accounting research: implications for financial reporting and opportunities for future research", Accounting and Finance, vol. 40, no. 2: 7-31

Barth, M.E. \& Clinch, G. (1998) "Revalued financial, tangible, and intangible assets: association with share prices and non-market-based value estimates", Journal of Accounting Research, vol. 36, no. 3: 199-233

Barth, M.E. (2006) "Including estimates of the future in today's financial statements", Accounting Horizons, vol. 20, no. 3: 271-285

Barth, M.E., Beaver, W.H. \& Landsman, W.R. (2001) "The relevance of the value relevance literature for financial accounting standard setting: another view", Journal of Accounting and Economics, no. 31: 77-104

Barth, M.E., Clinch, G. \& Shibano, T. (2003) "Market effects of recognition and disclosure", Journal of Accounting Research, vol. 41, no. 4: 581-609

Barth, M.E., Landsman, W. \& Lang, M. (2008) "International standards and accounting quality", Journal of Accounting Research, vol. 46, no. 3: 467-498

Barthes, R. (1977) Image Music Text, London: Fontana Press

Basu, S. \& Waymire, G. (2008) "Has the importance of intangibles really grown? And if so, why?" Accounting and Business Research, vol. 38: 171-190

Basu, S. (1997) "The conservatism principle and the asymmetric timeliness of earnings", Journal of Accounting and Economics, no. 24: 3-37

Beattie, V., McInnes, B. \& Fearnley, S. (2004) "A methodology for analysing and evaluating narratives in annual reports: A comprehensive descriptive profile and metrics for disclosure quality attributes", Accounting Forum, no. 28: 205-236

Berkman, H., Jona, J. \& Soderstrom, N. (2018) "Cybersecurity awareness and market valuation”, Journal of Accounting and Public Policy, no. 37: 508-526 
Białek-Jaworska, A. (2016) "A scientist in the board effect on recognition of R\&D outcomes in private firms' reports, Accounting and Management Information Systems, vol. 15, no. 4: 683-709

Biondi, Y. \& Reberioux, A. (2012) "The governance of intangibles: rethinking financial reporting and the board of directors", Accounting Forum, vol. 36, no. 4: 279-293

Blair, M. \& Wallman, S. (2003) "The growing intangibles reporting discrepancy", in Hand, J. \& Lev, B. (Eds) Intangible Assets: Values, Measures, and Risks, Oxford University Press, New York, NY: 451-468

Blair, M. M. \& Wallman, S. M. H. (2000) Unseen Wealth: Report of the Brookings Task Force on Understanding Intangibles Sources of Value, Washington, DC: The Brookings Institution Press

Bloom, M. (2008) Double accounting for goodwill: a problem redefined, London: Routledge

Bloom, M. (2009) “Accounting for goodwill”, Abacus, vol. 45, no. 3: 379-389

Boesso, G. \& Kumar, K. (2007) "Drivers of corporate voluntary disclosure", Accounting, Auditing \& Accountability Journal, vol. 20, no. 2: 269-296

Bond, S. \& Cmmins, J (2000) "The stock market and investment in the new economy: some tangible facts and intangible fictions", Brookings Papers on Economic Activity, no. 1: 61-124

Bonner, S.E., Hesford, J.W., Van der Stede, W.A. \& Young, S.M. (2006) "The most influential journals academic", Accounting Organizations and Society, vol. 31, no. 7: 663-685

Boone, J.P. \& Raman, K.K. (2001) "Off-balance sheet R\&D assets and market liquidity", Journal of Accounting and Public Policy, vol. 20, no. 1: 97-128

Borkowski, S.C. (2011) "Transfer pricing of intangible property. Harmony and discord across five countries", The International Journal of Accounting, no. 36: 349-374

Bourdieu, P. (1986) The Forms of Capital. In: Richardson JG (ed.) The handbook of theory and research for the sociology of education, New York, NY: Greenwood Press: 241-258

Bronnenberg, B. (2009) "Brand history, geography, and the persistence of brand shares", Journal of Political Economy, no. 117: 87-115

Brown, R. \& Jones, M. (2015) "Mapping and exploring the topography of contemporary financial accounting research", The British Accounting Review, vol. 47: 237-261

Callen J.L. (2015) "A selective critical review of financial accounting research", Critical Perspectives on Accounting, no. 26: 157-167

Canibano, L., Garcia-Ayuso, M. \& Sanchez, P. (2000) "Accounting for intangibles: A literature review", Journal of Accounting Literature, no. 19:102-130

Carlucci, D. \& Schiuma, G. (2007) "Assessing the role of knowledge assets in value creation dynamics by using the Analytic Network Process", Paper presented at the IC Congress, May, Amsterdam 
Chambers, R.J. (1997) "Wanted: Foundations of accounting measurement”, Abacus, no. $341: 36-47$

Chen, L., Danbolt, J. \& Holland, J. (2014) "Rethinking bank business models: The role of intangible", Accounting, Auditing \& Accountability Journal, vol. 27, no. 3: $563-589$

Chen, L., Danbolt, J. \& Holland, J. (2018) "Information about bank intangibles, analyst information intermediation, and the role of knowledge and social forces in the "market for information" Accounting Forum, no. 42: 261-276

Clausen, S. \& Hirth, S. (2016) "Measuring the value of intangibles", Journal of Corporate Finance, no. 40: 110-127

Corrado, C., Haskel, J., Jona-Lasinio, C. \& Iommi, M (2012) "Intangible capital and growth in advanced economies: measurement methods and comparative results", IZA Discussion Paper no. 6733

Corrado, C., Hulten, C. \& Sichel, D. (2009) "Intangible capital and US economic growth", Review of Income Wealth, vol. 55, no.3: 661-685

Court, D., Elzinga, D., Mulder, S. \& Vetvik O.J. (2009) "The consumer decision journey", McKinsey Quarterly 2009 Number 3, available online at: https://www.mckinsey.com/ /media/McKinsey/Business\%20Functions/Mar keting\%20and\%20Sales/Our\%20Insights/The\%20consumer\%20decision\%2 0journey/The\%20consumer\%20decision\%20journey.ashx

Curmei, C.V., Dinca, L.E., Curmei, I.A \& Semenescu, A. (2018) "The influence of the strategic financial policies on share valuation in an unstable economic environment", Proceedings of ICBE, vol. 12, no.1: 241-250

Dahmash, F., Durand, R. \& Watson, J. (2009) "The value relevance and reliability of reported goodwill and identifiable intangible assets", The British Accounting Review, vol. 41, no. 1: 120-137

Dahmash, F.N. \& Qabajeh, M. (2012) "Value relevance of Ohlson Model with Jordanian data", Interdisciplinary Journal of Contemporary Research in Business, vol. 3, no. 11: 551-560

Daum, J.H. (2003) Intangible Assets and Value Creation, England: John Wiley \& Sons Ltd

Davison, J. \& Skerratt, L. (2007) "Words, pictures and intangibles in the corporate report", Edinburgh: The Institute of Chartered Accountants of Scotland

Davison, J. (2010) "[In]visible [in]tangibles: Visual portraits of the business élite", Accounting, Organizations and Society, no. 35: 165-183

Deegan, C. (2000) Financial Accounting Theory, Sydney: McGraw-Hill Book Company

Dehning, B., Pfeiffer, M.G. \& Richardson, V.J. (2006) “Analysts' forecasts and investments in information technology", International Journal of Accounting Information Systems, no. 7: 238-250

Dodds, W.B., Monroe, K.B. \& Grewal, D. (1991) "Effect of price, brand, and store information on buyers' product evaluations", Journal of Marketing Research, no. 28: 307-319 
Duizabo, S. \& Guillaume, N. (1996) "Approche d'une nouvelle typologie des actifs immatériels', Echanges, no. 119: 34-39

Eckstien, C. (2004) "The measurement and recognition of intangible assets: then and now", Accounting Forum, vol. 28, no. 2: 139-158

Edmans, A. (2011) "Does the stock market fully value intangibles? Employee satisfaction and equity prices", Journal of Financial Economics, no. 101: 621-640

Egginton, D. (1990) "Towards some principles for intangible asset accounting", Accounting and Business Research, vol. 20, no. 79: 193

Elbannan, M.A. \& Elbannan M.A (2014) "Economic consequences of bank disclosure in the financial statements before and during the financial crisis evidence from Egypt", Journal of Accounting, Auditing and Finance, vol. 30, no. 2, DOI: $10.1177 / 0148558 X 14552723$

Elbannan, M.A. \& Elbannan, M.A. (2015) "Information content of SFAS 157 fair value reporting", Journal of International Accounting, Audit and Taxation, no. 25 : $31-45$

Elliott, R. \& Jacobson, P. (1991) "US accounting: A national emergency”, Journal of Accountancy, no. 172: 54-58

El-Tawy, N. \& Tollington, T. (2013) "Some thoughts on the recognition of assets, notably in respect of intangible assets", Accounting Forum, no. 37: 67-80

Enache, L., Li, L. \& Riedl, E.J. (2017) "The disclosure of good versus bad news: evidence from the biotech industry", available online at: https://caremendoza.nd.edu/assets/287969/eriedl_paper_elr_2018_08_24_for_notre_da me.pdf

Ene G. S., Chilarez, D. \& Dindire, L. M. (2013) "Relevance and credibility of the fair value measurement during the crisis", $1^{\text {st }}$ International Conference 'Economic Scientific Research - Theoretical, Empirical and Practical Approaches, ESPERA 2013

Engstrom, T., Westnes, P. \& Wetnes, S.F. (2003) "Evaluating intellectual capital in the hotel industry", Journal of Intellectual capital, vol. 4, no. 3: 287-303

Entwistle, G. (1999) "Exploring the R\&D disclosure environment", Accounting Horizons, vol. 13, no. 4: 323-341

Firer, S. \& Williams, M. (2003) "Intellectual capital and traditional measures of corporate performance", Journal of Intellectual Capital, vol. 4, no.3: 348-60

Fisher, I. (1930) The Theory of Interest, NY: Macmillan

García-Merino, J.D., Arregui-Ayastuy, G., Rodríguez-Castellanos, A. \& VallejoAlonso, B. (2011) "Motives for the financial valuation of intangibles, reasons and results", Business Science Reference

Gerpott, T.J., Thomas, S.E. \& Hoffmann, A.P. (2008) "Intangible asset disclosure in the telecommunications industry", Journal of Intellectual Capital, vol. 9, no. 1 : 37-61 
Goh, B.W., Li, D., Ng, J. \& Yong, K.O. (2015) "Market pricing of banks' fair value assets reported under SFAS 157 since the 2008 financial crisis", Journal of Accounting Public Policy, vol. 34, no. 2: 129-145

Goodwin, J. \& Ahmed, K. (2006) "Longitudinal value relevance of earnings and intangible assets: Evidence from Australian firms", Journal of International Accounting, Auditing and Taxation, 15: 72-91

Goodwin, J., Ahmed, K. \& Heaney, R. (2008) “The Effects of International Financial Reporting standards on the Accounts and Accounting Quality of Australian Firms: A Retrospective Study", Journal of Contemporary Accounting \& Economics, vol. 4, no. 2: 89-119

Grant, R. M. (1991) "The resource-based theory of competitive advantages: implications for strategy formulation", California Management Review, vol. 33, no. 3: 114-135

Gruber, S. (2015) Intangible Values in Financial Accounting and Reporting: An Analysis from the Perspective of Financial Analysts, St. Gallen, Switzerland: Springer Gabler

Hall, B. (2011) "Innovation and productivity", Nordic Economic Policy Review, no. 2: $167-203$

Hall, B.H., Jaffe, A. \& Trajtenberg, M. (2005) "Market value and patent citations", Journal of Economics, available online at: https://www.researchgate. net/publication/24049288_Market_Value_and_Patent_Citations

Hall, R. (1992) "The Strategic Analysis of Intangible Resource", Strategic Management Journal, vol. 13, no. 2:135-144

Hamel, G. \& Prahalad, C.K. (1994) Competing for the future, Boston: Harvard Business Press

Haskins, M. E. \& Sack, R. J. (2005) "Calling All Parties: Now is the Time to Call the Aid of the Balance Sheet", Business Horizons, vol. 48, no. 4: 325-335

Healy, P. \& Palepu, K. (2001) "Information asymmetry, corporate disclosure, and the capital markets: A review of the empirical disclosure literature", Journal of Accounting and Economics, vol. 31, no. 1-3: 405-440

Hicks, J. (1946) Value and Capital, $2^{\text {nd }}$ ed. Oxford: Oxford University Press

Hirschey, M. \& Richardson, V.J. (2002) "Information content of accounting goodwill numbers", Journal of Accounting and Public Policy, no. 21: 173-191

Hirschey, M. \& Weygandt, J. J. (1985) "Amortization Policy for Advertising and Research and Development Expenditures", Journal of Accounting Research, vol. 23 , no. 1 : 326-335

Huang, C.C., Luther, R., Tayles, M. \& Haniffa, R. (2013) "Human capital disclosures in developing countries: figureheads and value creators", Journal of Applied Accounting Research, vol. 14, no. 2: 180-196

Huang, H.W., Dao, M. \& Fornaro, J.M. (2016) "Corporate governance, SFAS 157 and cost of equity capital: Evidence from US financial institutions", Review of Quantitative Finance and Accounting, vol. 46, no. 1: 141-177 
Hughes, J. \& Kao, J. (1991) "Economic Implications of Alternative Rules for Research and Development Costs", Contemporary Accounting Research, 152-169

IAS 38 Intangible assets, available online at: https://www.ifrs.org/issuedstandards/list-of-standards/ias-38-intangible-assets/

IASB (2010) The Conceptual Framework for Financial Reporting, available online at: http://eifrs.ifrs.org/eifrs/bnstandards/en/framework.pdf

IASB (2014) IAS 38 Intangible assets, available online at: http://eifrs.ifrs.org/eifrs/bnstandards/en/IAS38.pdf

IASB (2017) Better Communication in Financial Reporting Making disclosures more meaningful, available online at: https://www.ifrs.org//media/project/disclosure-initative/better-communication-makingdisclosures-more-meaningful.pdf

IASB (2018) Project summary Conceptual Framework for Financial Reporting, available online at: https://www.ifrs.org/-/media/project/conceptualframework/fact-sheet-project-summary-and-feedback-statement/conceptualframework-project-summary.pdf

ICAEW, ICAEW thought leadership information for better markets, Measurement in financial reporting, 2006, https://www.icaew.com//media/corporate/files/technical/financial-reporting/information-for-bettermarkets/ifbm-prospectus.ashx?la=en

Ienciu, N.M. \& Matiș, D. (2014) "Inflection points in the development of IAS 38", Journal of Financial Reporting and Accounting, vol. 12, no. 1: 62-75

Ishak, F., Ghani, A. \& Hasmini, N. (2013) "A review of the literature on brand loyalty and customer loyalty", Conference on Business Management Research, Universiti Utara Malaysia, Sintok

Ittner, C.D. (2008) "Does measuring intangibles for management purposes improve performance? A review of the evidence", Accounting and business research, vol. 38, no 3

Jeny, A. \& Modovan, R. (2016) "Recognition and Disclosure of Intangible Assets A Review and Framework", The European Accounting Association, 39 Annual Congress, Maastricht, 11-13 May 2016

Jenkins, E. \& Upton, Jr., W. S. (2001) "Internally generated intangible assets: framing the discussion", Australian Accounting Review, vol. 11, no. 2: 4-11

Jensen, M. \& Meckling, W. (1976) "Theory of the firm: managerial behavior, agency costs and ownership structure", Journal of Financial Economics, vol. 3, no. 4: 305-360

Johanson, U., Martensson, M. \& Skoog, M. (2001) "Measuring to understand intangible performance drivers", European Accounting Review, vol. 10, no. 3: 407-437

Johansson, S.E, Hjelstrom, T. \& Hellman, N. (2016) “Accounting for goodwill under IFRS: A critical analysis", Journal of International Accounting, Auditing and Taxation, no. 27: 13-25 
Johnson, L. T. \& Petrone, K.R. (1998) “Is goodwill an asset?”, Accounting Horizons, vol. 12, no. 3: 293-303

Kadous, K., Koonce, L.\& Thayer, J. (2012) "Do Financial Statement Users Judge Relevance Based on Properties of Reliability?", The Accounting Review, vol. 87, no. 4: 1335-1356

Kallapur, S. \& Kwan, S.Y.S. (2004) "The value relevance and reliability of brand assets recognized by UK firms", The Accounting Review, vol. 79, no. 1: $151-172$

Kang, H.H. \& Gray, S.J. (2011) "Reporting intangible assets: Voluntary disclosure practices of top emerging market companies", The International Journal of Accounting, no. 46: 402-423

Kaufmann, L. \& Schneider, Y. (2004) "Intangibles: A Synthesis of Current Research", Journal of Intellectual Capital, vol. 5, no 3

Keller, K.L. (2008) Strategic Brand Management: Building, Measuring and Managing Brand Equity, Upper Saddle River, NJ: Pearson Education

Khalidi, M.A. (2013) Natural categories and human kinds Classification in the natural and social sciences, Cambridge University Pres

Kothari, S.P., Laguerre, T. \& Leone, A. (2002) "Capitalization versus expensing: evidence on the uncertainty of future earnings from capital expenditures versus R\&D outlays", Review of Accounting Studies, no. 7: 355-382

KPMG (2004) "Financial reporting matters", December, 2004, issue 3

Krolick, D. (2005) "The relevance of financial statement information for executive performance evaluation: Evidence from choice of bonus plan accounting performance measures", The International Journal of Accounting, no. 40: $115-132$

Kumar, G. (2013) "Voluntary disclosures of intangibles information by U.S.- listed Asian companies", Journal of International Accounting, Auditing and Taxation, no. 22: 109-118

Larkin, Y. (2013) "Brand perception, cash flow stability, and financial policy", Journal of Financial Economics, no. 110: 232-253

Lev, B. \& Penman, S. (1990) "Voluntary forecast disclosure, nondisclosure, and stock prices", Journal of Accounting Research, vol. 28, no. 1: 49-76

Lev, B. \& Sougiannis, T. (1999) "Penetrating the book-to-market black box: The R\&D effect", Journal of Business Finance and Accounting, vol. 26, no. 3-4: 419-460

Lev, B. \& Zarowin, P. (1999) "The boundaries of financial reporting and how to extend them", Journal of Accounting Research, Autumn: 252-285.

Lev, B. (2001) Intangibles: Management, Measurement and Reporting, Washington: The Brookings Institution Press

Lev, B. (2002) "Where have all of Enron"e s intangibles gone?", Journal of Accounting and Public Policy, vol. 21: 131-135

Lev, B. (2004) "Sharpening the Intangible Edges", Harvard Business Review: $109-116$ 
Lev, B. (2008) “A rejoinder to Douglas Skinner"s „Accounting for intangibles - a critical review of policy recommendation", Accounting and business research, vol. 38, no. 3: 209-214

Lev, B., Radhakrishnan, S. \& Zhang, W. (2009) "Organization capital”, Abacus, vol. 45 , no. 3:275-311

Levine, O. (2017) "Acquiring growth", Journal of Financial Economics, no. 126: 300-319

Liebowitz, J. \& Suen, C.Y. (2000) "Developing knowledge management metrics for measuring intellectual capital", Journal of Intellectual Capital, no. 1: 54-67

Lin, X. (2009) "Endogenous Technological Progress and the Cross Section of Stock Returns", Discussion paper, no. 634

Lin, Y.H, Fornaro, S.L. \& Solomon Huang H.W. (2017) "Fair value measurement and accounting restatements", Advances in Accounting, no. 38: 30-45

Lonergan, W. (2009) "Discussion of Bloom", Abacus, vol. 45, no.3: 390

Lonnqvist, A. (2002) "Measurement of intangible assets - an analysis of key concepts", Frontiers of e-business research: 275-294

Luft, J.T. \& Shields, M.D. (2001) "Why does fixation persist? Experimental evidence on the judgment performance effects of expensing intangibles", Accounting Review, vol. 76, no. 4: 561-587

Lungu, C.I., Caraiani, C., Dascalu, C., Turcu, D. \& Turturea, M. (2016) “Archival analysis of Corporate Social Responsibility research: The Romanian perspective", Accounting and Management Information Systems, vol. 15, No. 2, pp. 341-371, 2016

Malik, E.M., Ghafoor, M.M, Iqbal, H.K, Ali, Q., Hunbal, H., Noman, M. \& Ahmad, B. (2013) "Impact of brand image and advertisement on consumer buying behavior", World Applied Sciences Journal, vol. 23, no. 1: 117-122

Martin-Oliver, A. \& Salas-Fumás, V. (2007) "How do intangible assets create economic value? an application to banks", Banco de España Research Paper, no. WP-0730. Available at SSRN: https://ssrn.com/abstract=1020685 or http://dx.doi.org/10.2139/ssrn.1020685

Mouritsen, J., Larsen, H., Bukh, P.N. \& Johansen, M. (2001) "Reading an Intellectual Capital Statement: Describing and prescribing knowledge management strategies", Journal of Intellectual Capital, vol. 2, no. 4: 359-383

Murthi, B.P.S. \& Srinivasan, K. (1999) "Consumers' extent of evaluation in brand choice", Journal of Business, vol. 72, no. 2, available at SSRN: https://ssrn.com/abstract=146748

Neu, D, Wasame, H. \& Pedwell, K. (1998) "Managing public impressions: environmental disclosures in annual reports", Accounting, Organisations and Society, vol. 23, no. 3: 265-89

Nils, E., Huegh-Krohn J. \& Knivsfla, K. H. (2000) "Accounting for intangible assets in Scandinavia, the UK, the US, and by the IASC: Challenges and a solution", The International Journal of Accounting, vol. 35, no. 2: 243-265 
Nobes, C. (2001) Asset Measurement Bases in UK and IASC Standards, London: Certified Accountants Educational Trust

Nobes, C. (2018) "Lessons from misclassification in international accounting", The British Accounting Review, no. 50: 239-254

OECD (2011) A new OECD project. New sources of growth: intangible assets, available online at: https://www.oecd.org/sti/inno/46349020.pdf

Orens, R., Aerts, W. \& Lybaert, N. (2009) "Intellectual capital disclosure cost of finance and firm value", Management Decision, vol. 47, no. 10: 1536-1554

Ochs, P. (1996) "Mieux mesurer l'investissement immatériel", Echanges, no. 570: 48-50

Penman, S.H. (2006) "Handling valuation models", Journal of Applied Corporate Finance, no. 18: 48-55

Penman, S.H. (2007) "Financial reporting quality: Is fair value a plus or a minus?", Accounting and Business Research, vol. 37, no. 1: 33-44

Penman, S.H. (2009) "Accounting for intangible assets: there is also an income statement”, Abacus, vol. 45, no. 3: 358-371

Petty, R., Ricceri, F. \& Guthrie, J. (2008) "Intellectual capital: A user's perspective", Management Research News, vol. 31, no. 6: 434-447

Plantin, G., Sapra, H. \& Shin, H.S. (2005) "Fair value accounting and financial stability", available at: http://ssrn.com/abstract $=1275395$

Pozen, R.C. (2009) "Is it fair to blame fair value accounting for the financial crisis?" Harvard Business Review, vol. 87, no. 11: 85-92

Prieto, I.M. \& Revilla, E. (2006) "Assessing the impact of learning capability on business performance: empirical evidence from Spain", Management Learning, vol. 37, no. 4: 499-522

Radenovic, T. \& Krstic, B. (2017) "Intellectual capital as the source of competitive advantage: the resource-based view", Facta Universitatis Series: Economics and Organization, vol. 14, no 2: 127-137

Ramirez-Corcoles, Y. \& Ponce, A.T. (2013) "Cost-benefit analysis of intellectual capital disclosure: University stakeholders'view”, Revista de ContabilidadSpanish Accounting Review, vol. 16, no. 2: 106-117

Rao, A.R. \& Monroe, K.B. (1989) "The effect of price, brand name, and store name on buyers' perceptions of product quality: an integrative review", Journal of Marketing Research, no. 26: 351-357

Rappaport, A. (2006) "10 Ways to create shareholder value", Harvard Business Review, vol. 84, no. 9:66-77

Reilley, R. \& Schweihs, R. (2014) Guide to Intangible Asset Valuation, American Institute of Certified Public Accountants, New York: American Institute of Certified Public Accountants, Inc.

Riahi-Belkaoui, A. (2003) "Intellectual capital and the firm performance of US multinational firms: A study of the resources-based and stakeholder's views, Journal of Intellectual capital, vol. 4, no. 2: 215-226 
Riedl, E. J. \& Serafeim, G. (2011) "Information Risk and Fair Values: An Examination of Equity Betas", Journal of Accounting Research, vol. 49, no. 4: 1083-1122

Ross, G. \& Ross, J. (1997) "Measuring your company's intellectual performance", Long Range Planning, no. 30: 413-426

Ryan, B., Scapens, R.W. \& Theobald, M. (2002) Research method and methodology in finance and accounting, $2^{\text {nd }}$ ed., Mitcham, Surrey: International, Padstow, Cornwall

Ryan, S.G. (2008) "Accounting in and for the subprime crisis", Accounting Review, vol. 83 , no. 6: $1605-1638$

Ryan, S.G. (2011) "Financial reporting for financial instruments", Foundations and Trends in Accounting, vol. 6, no. 3-4: 187-354

Sadowska, B. \& Lulek, A. (2016) "Measuring and valuation in accounting theoretical basis and contemporary dilemmas", World Scientific News, no. 56: 247-256

Saenz, J. (2005) "Human capital indicators, business performance and market-tobook ratio", Journal of Intellectual Capital, vol. 6, no. 3: 374-384

Schoderbek, M.P. \& Slaubaugh, M.D. (2001) "The FASB exposure draft on accounting for business combinations and intangible assets: an instructional assignment, Journal of Accounting Education, no. 19: 265-281

Seow, G., Shangguan, Z. \& Vasudevan, G. (2006) "Intangible investments and the cost of equity capital", The International Journal of Finance, vol. 18, no. 2: 3980-4012

Shah, S.Z.A., Stark, A.W \& Akbar, S. (2009) "The value relevance of major media advertising expenditures: Some U.K. evidence', The International Journal of Accounting, no. 44: 187-206

Singhvi, S. \& Desai, H. (1971) "An empirical analysis of the quality of corporate financial disclosure", The Accounting Review, vol. 46, no. 1: 129-138

Skinner, D. J. (2008) "Accounting for Intangibles: A Critical Review of Policy Recommendations", Accounting and Business Research, vol. 38, no. 3: 191-204

Srivastava, A. (2014) "Why have measures of earnings quality changed over time?", Journal of Accounting and Economics, no. 57: 196-217

Starr, M.K. \& Rubinson, J.R. (1978) "A loyalty group segmentation model for brand purchasing simulation", Journal of Marketing Research, no. 15: 378-383

Staubus, G.J. (2004) "Two views of accounting measurement", Abacus, vol. 40, no. 3:265-279

Steenkamp, N. \& Northcott, D. (2007) "Content Analysis in Accounting Research: The Practical Challenges”, Australian Accounting Review, vol. 17, no. 3: $12-25$

Stewart, T. (1997) Intellectual Capital, London: Nicolas Brealey Publishing 
Stolowy, H. \& Jeny-Cazavan, A. (2001) "International accounting disharmony: the case of intangibles", Accounting, Auditing and Accountability Journal, vol. 14, no. 4: 477-496

Stolowy, H., Haller, A. \& Klockhaus, V. (2001) “Accounting for brands in France and Germany compared with IAS 38 (intangible assets): An illustration of the difficulty of international harmonization", The International Journal of Accounting, no. 36: 147-167

Sullivan, P.H. \& Wurzer, A.J. (2009) "Ten common myths about intangibles value and valuation", Intellectual Asset Management, vol. 27, no. 17

Sun, Q. \& Xiaolan, M. (2018) "Financing intangible capital", available online at: http://www.eief.it/files/2015/08/zhang.pdf

Tan, H.P., Plowman, D \& Hancock, P. (2007) "Intellectual capital and the financial returns of companies, Journal of Intellectual capital, vol. 8, no. 1: 76-95

Trabelsi, S., Labelle, R. \& Dumontier, P. (2008) "Incremental voluntary disclosure on corporate websites, determinants and consequences", Journal of Contemporary Accounting \& Economics, vol. 4, no. 2: 120-155

Upton, Jr., W. S. (2001) "Business and financial reporting - challenges from the new economy", Financial Accounting Series: FASB

Uzma S.H. (2011) "Challenges of reporting intangible assets in financial statements", The Journal of Accounting Research \& Audit Practices, vol. X, no. $4: 28-38$

Vallejo-Alonso, B. (2010) Identifying, Measuring, and Valuing Knowledge-Based Intangible Assets: New Perspectives, IGI Global

Vidrascu, P. A. (2013) "The complexity classification of intangible assets", Hyperion Economic Journal, no. 1: 42-50

Walker, R.G. (2009) "Discussion of Lev, Radhakrishnan and Zhang", Abacus, vol. 45 , no. 3: $299-311$

Wallace, R.S.O., Naser, K. \& Mora, A. (1994) "The relationship between comprehensiveness of corporate annual reports and firm characteristics in Spain”, Accounting and Business Research vol. 25, no. 97: 41-53

Wallison, P. J. (2008) "Fair value accounting: a critique" American Enterprise Institute for Public: Policy Research, AEI Outlook Series, July 2008, available online at, http://www.aei.org/docLib/20080728_23336July FSOg.pdf.

Wang, X., Garcia, F., Guijarro, F. \& Moya, I. (2010) "Evaluating patent portfolios by means of multicriteria analysis", Revista de Contabilidad-Spanish Accounting Review, vol. 14, no. 1: 9-27

Willet, R.J. (1988) "An axiomatic theory of accounting measurement", Accounting and Business Research: vol. 19, no. 73: 79-91

Wyatt, A. (2005) "Accounting recognition of intangible assets: theory and evidence on economic determinants", Accounting Review, vol. 80, no. 3: 967-1003

Wyatt, A. (2008) "What financial and non-financial information on intangibles is value relevant? A review of the evidence", Accounting and Business Research, vol. 38, no. 3: 217-256 
Yao (Troy), D.F., Percy, M. \& Hu, F. (2015) "Fair value accounting for non-current assets and audit fees: Evidence from Australian companies", Journal of Contemporary Accounting \& Economics, no. 11: 31-45

Zeghal, D. \& Maaloul, A. (2011) "The accounting treatment of intangibles - A critical review of the literature", Accounting Forum, no. 35: 262-274

Zeghal, D. (2000) "New assets for the new economy", FMI Journal, vol. 11, no. 2: $35-40$ 